\title{
A qualitative and quantitative comparison of mite fauna between bifenthrin-treated and non-pesticide treated alfalfa hay fields in Central Greece
}

\author{
E.G. Badieritakis ${ }^{1 *}$, A.A. Fantinou ${ }^{2}$ and N.G. Emmanouel ${ }^{1}$
}

Summary The mite fauna in foliage and litter of a sprayed alfalfa hay field with the acaricide-insecticide bifenthrin, was studied based on monthly samplings from foliage and litter in Central Greece between 2008-2009. Potential differentiations between this field and two adjacent alfalfa hay fields, which were not subjected to pesticide applications and were managed with different number of cuttings, were also evaluated in terms of population fluctuation over time, population density, species richness, diversity and spatial distribution. The sprayed field hosted 50 and 68 species and morphospecies in foliage and litter respectively, depicting high relative abundance of oribatid and prostigmatic mites. Neoseiulus aristotelisi Papadoulis, Emmanouel and Kapaxidi, was a new record for alfalfa, previously found in rice in Macedonia, Greece. The seasonal fluctuation of mites, particularly in foliage, was similar in all fields. The spatial distribution of a Zygoribatula species, which was common and dominant in all fields, was also aggregated. Finally, the sprayed field shared similar mite diversity with the two non-sprayed fields, but not similar species richness.

Additional keywords: alfalfa, bifenthrin, mites, qualitative, quantitative study

\section{Introduction}

The ecological role of mites in terrestrial ecosystems is significant, since they can be plant pests, predators of other mites and insects (e.g. phytoseiid mites as thrips predators), decomposers, detritivores, scavengers, and parasites (Sabelis and Van Rijn, 1997; Schneider et al., 2004; Krantz, 2009). Apart from faunistical surveys, a lot of work has been carried out within the framework of studying the impact of agricultural practices, such as the use of slurry in combination with tillage (Bosch-Serra et al., 2014) or postmining restoration treatments (Andrés and Mateos, 2006) on the population density, species richness and diversity of soil mites. Several studies have also emphasized population parameters of mites of the aerial part

\footnotetext{
'Laboratory of Agricultural Zoology and Entomology, Agricultural University of Athens, lera Odos 75, Votanicos, GR-118 55 Athens, Greece.

2 Laboratory of Ecology and Environmental Sciences, Agricultural University of Athens, lera Odos 75, Votanicos, GR-118 55 Athens, Greece.

*Corresponding author: ebadieritakis@yahoo.gr
}

of crops. For instance, Wissuwa et al. (2012) studied how habitat age and plant species affected mesostigmatic mites in grassy arable fallows in Eastern Austria in terms of population density, species richness and diversity. The spatial distribution of mites has been limitedly studied worldwide, although new research has been added over the last few years. For instance, Alatawi et al. (2011) studied how the spatial patterns of Phytoseiulus persimilis Athias-Henriot (Phytoseiidae) and its prey, Tetranychus urticae Koch (Tetranychidae), affect the biological control of the latter in a greenhouse.

Alfalfa or lucerne is a major crop in Greece cultivated for hay production. According to the most recent published state statistical data (2016), the total cultivated area with alfalfa and other perennial clovers in Greece is about 119,723 ha or $46 \%$ of total cultivated area with hay plants in the country producing 1,369,377 t of hay (Hellenic Statistical Authority, 2019). Although alfalfa cuttings help remove arthropod pests hosted in foliage, pyrethroid insecticides, such as bifenthrin, may be used to control lucerne flower gallmidge (Contarinia medicaginis Kieffer) (Dip- 
tera: (ecidomyidae) in Greece.

Despite the economic importance of this crop in Greek agriculture, little is known about the mite fauna of alfalfa in Greece. In this respect, Badieritakis et al. (2014) contributed with results regarding qualitative and quantitative information over mite assemblages of foliage and litter mites of two considerably similar and non-pesticide treated alfalfa hay fields in Central Greece, which only differed in the number of cuttings. In that study we found that the population fluctuation of mites in the foliage of both fields was similar, unlike that of litter. The population density of mites also significantly differed between the fields except for Prostigmata. Moreover, litter was more species abundant in the less harvested hay field, although the opposite was observed in the foliage of that field when compared to the foliage of the more harvested field. The latter also exhibited higher mite diversity apart from Prostigmata. Finally, the spatial distribution of mites was aggregated in all habitats.

Based on these findings (Badieritakis et al., 2014), the present work has as main objective to compare the mite fauna as well as the relative abundance of mites in the foliage and litter of a bifenthrin-treated alfalfa hay field located in the same area (approximately 100 meters away) with the non-pesticide treated fields as well as the species richness, diversity and spatial distribution of mites in the foliage and litter.

\section{Materials and methods}

\section{Sampling sites}

This study took place between 2008 and 2010 within the experimental farm of Agricultural University of Athens in Kopais Valley (Central Greece) $\left(38^{\circ} 23^{\prime} 51.68^{\prime \prime} \mathrm{N}\right.$, $\left.23^{\circ} 5^{\prime} 23.87^{\prime \prime} \mathrm{E}\right)$. The field used for this purpose was about $1,000 \mathrm{~m}^{2}$ and succeeded a maize crop. This field, thereafter indexed as " $C$ ", was approximately $100 \mathrm{~m}$ away from those reported as field A and field B by Badieritakis et al. (2014), and was subject to the same agricultural practices and sown with the same alfalfa cultivar on the same day with the others. All fields were cut between May and October every year. Both fields, A and C, were harvested once a month on the same day, in comparison to field B which was cut almost bimonthly. In addition, field $C$ was also sprayed with bifethrin $100 \mathrm{~g} / \mathrm{l} \mathrm{EC}$ in August and October 2008 and approximately bimonthly between March and September 2009. This pesticide was applied by local farmers at the application rate of $25 \mathrm{ml} / 50 \mathrm{I}$ per $1,000 \mathrm{~m}^{2}$ to control the population of $C$. medicaginis.

\section{Sampling procedure and identification of mites}

The sampling procedure and mite identification has been described by Badieritakis et al. (2014). In total, 240 foliage samples and 288 litter samples ( 10 foliage samples and 12 litter samples collected once a month) were randomly collected from each field during the two-year sampling period (2008-2010) with metallic quadrats of $25^{*} 40 \mathrm{~cm}$ for foliage sampling and $14^{*} 16 \mathrm{~cm}$ for litter sampling. Mites were extracted with a modified apparatus following the Berlese-Tullgren method in the laboratory and identified to species and morphospecies (e.g. sp1, sp2, etc. or species $A, B$, etc.) based only on adult mites (Minor and Cianciolo, 2007). The Orders and suborders of main interest under study were Mesostigmata, Sarcoptiformes: Oribatida and Trombidiformes: Prostigmata. Morphospecies were used in cases were identification was difficult due to lack of suitable dichotomous keys or mite species descriptions. Due to unsuitability of the Berlese-Tullgren method for extracting eriophyid and tetranychid mites (Badieritakis et al., 2014), the latter were only recorded in Table 1 without being quantified. The dry weight of samples was also recorded for comparison reasons.

\section{Data analysis}

The classification of mite taxa as dominant, influent or recedent was carried out according to specific criteria of dominance (Palyvos 
Table 1. Taxa, relative abundance (\%) and total counts of adults and juveniles of mites recorded in foliage and litter of a bifenthrin-sprayed alfalfa field in Kopais Valley (Central Greece), between 2008-2010.

\begin{tabular}{|c|c|c|}
\hline \multirow{2}{*}{ TAXA } & \multicolumn{2}{|c|}{ Relative abundance (\%) } \\
\hline & Foliage & Litter \\
\hline Order Mesostigmata Canestrini & $0.91 R$ & $1.85 \mathrm{R}$ \\
\hline \multicolumn{3}{|l|}{ Ameroseiidae Evans } \\
\hline Ameroseius sp. & - & - \\
\hline Kleemania sp. & $0.01 \mathrm{R}$ & $0.01 \mathrm{R}$ \\
\hline \multicolumn{3}{|l|}{ Ascidae Voights \& Oudemans } \\
\hline Arctoseiodes sp. & $0.01 \mathrm{R}$ & $0.04 \mathrm{R}$ \\
\hline Arctoseius sp. & - & - \\
\hline Asca bicornis Canestrini \& Fanzago ${ }^{1}$ & - & - \\
\hline Gamasellodes sp. & $0.03 R$ & $0.21 \mathrm{R}$ \\
\hline Protogamasellus sp. & $0.01 \mathrm{R}$ & $0.10 \mathrm{R}$ \\
\hline \multicolumn{3}{|l|}{ Blattisociidae Garman } \\
\hline Blattisocius sp. & $0.01 \mathrm{R}$ & $0.01 R$ \\
\hline Cheiroseius sp. & - & - \\
\hline Lasioseius sp. & $0.18 \mathrm{R}$ & $0.15 R$ \\
\hline \multicolumn{3}{|l|}{ Digamasellidae Evans } \\
\hline Dendrolaelaps sp. & - & - \\
\hline \multicolumn{3}{|l|}{ Laelapidae Berlese } \\
\hline Gymnolaelaps sp. & - & - \\
\hline Hypoaspis sp. & $0.03 R$ & $0.30 \mathrm{R}$ \\
\hline Laelaps sp. & - & $0.01 R$ \\
\hline Ololaelaps sp. & - & - \\
\hline \multicolumn{3}{|l|}{ Macrochelidae Vitzthum } \\
\hline Macrocheles sp. & - & - \\
\hline \multicolumn{3}{|l|}{ Pachylaelapidae Berlese } \\
\hline Pachylaelaps sp. & - & - \\
\hline \multicolumn{3}{|l|}{ Parasitidae Oudemans } \\
\hline Paragamasus sp. & - & - \\
\hline Parasitus sp. & - & $0.08 \mathrm{R}$ \\
\hline \multicolumn{3}{|l|}{ Phytoseiidae Berlese } \\
\hline Amblyseius andersoni (Chant) ${ }^{1}$ & - & - \\
\hline Neoseiulus aristotelisi Papadoulis, Emmanouel and Kapaxidi ${ }^{1}$ & $0.01 \mathrm{R}$ & $0.01 R$ \\
\hline Neoseiulus barkeri Hughes & $0.27 R$ & $0.28 \mathrm{R}$ \\
\hline Neoseiulus bicaudus (Wainstein) ${ }^{1}$ & - & - \\
\hline Proprioseiopsis messor (Wainstein) & - & - \\
\hline Typhlodromus kerkirae Swirski \& Ragusa & - & - \\
\hline \multicolumn{3}{|l|}{ Uropodoidea. not identified to Family } \\
\hline Uropodoidea (one species) & - & - \\
\hline Juveniles of Mesostigmata† & 0.35 & 0.65 \\
\hline Order Sarcoptiformes Reuter & 74.71D & 85.41D \\
\hline \multicolumn{3}{|l|}{ Suborder Endeostigmata Reuter } \\
\hline \multicolumn{3}{|l|}{ Alycidae Canestrini \& Fanzago } \\
\hline Alycidae (one species) & $0.01 R$ & $0.13 R$ \\
\hline \multicolumn{3}{|l|}{ Nanorchestidae Grandjean } \\
\hline Nanorchestidae (one species) & $0.02 \mathrm{R}$ & $0.01 R$ \\
\hline \multicolumn{3}{|l|}{ Terpnacaridae Grandjean } \\
\hline Terpnacaridae (one species) & $0.01 R$ & $0.01 \mathrm{R}$ \\
\hline Suborder Oribatida van der Hammen & 74.67D & $85.26 \mathrm{D}$ \\
\hline \multicolumn{3}{|l|}{ Acaridae Latreille } \\
\hline Rhizoglyphus sp. & - & $0.05 R$ \\
\hline Thyreophagus sp. & $0.01 \mathrm{R}$ & $0.02 \mathrm{R}$ \\
\hline Tyrophagus curvipenis Fain \& Fauvel & $0.01 R$ & $0.02 \mathrm{R}$ \\
\hline Tyrophagus longior (Gervais) & $0.43 R$ & $0.51 \mathrm{R}$ \\
\hline Tyrophagus similis Volgin & $0.05 R$ & $0.05 R$ \\
\hline Tyrophagus palmarum Oudemans sensu Robertson & $0.05 R$ & $0.48 \mathrm{R}$ \\
\hline
\end{tabular}




\begin{tabular}{|c|c|c|}
\hline \multirow{2}{*}{ TAXA } & \multicolumn{2}{|c|}{ Relative abundance (\%) } \\
\hline & Foliage & Litter \\
\hline Tyrophagus perniciosus Zakhvatkin & $0.08 \mathrm{R}$ & $0.24 \mathrm{R}$ \\
\hline Tyrophagus putrescentiae (Schrank) & $0.03 R$ & $0.03 R$ \\
\hline \multicolumn{3}{|l|}{ Brachychthoniidae Thor } \\
\hline \multicolumn{3}{|l|}{ Chortoglyphidae Berlese } \\
\hline \multicolumn{3}{|l|}{ Epilohmanniidae Oudemans } \\
\hline \multicolumn{3}{|l|}{ Euphthiracaridae Jacot } \\
\hline \multicolumn{3}{|l|}{ Oppiidae Grandjean } \\
\hline Berniniella sp. & - & $0.01 R$ \\
\hline \multicolumn{3}{|l|}{ Oribatellidae Jacot } \\
\hline Oribatella sp1 & - & $0.03 R$ \\
\hline Oribatella sp2 & - & - \\
\hline \multicolumn{3}{|l|}{ Oribatulidae Thor } \\
\hline Zygoribatula sp1 & $0.84 \mathrm{R}$ & 5.411 \\
\hline Zygoribatula sp2 & $0.13 R$ & $1.62 \mathrm{R}$ \\
\hline Zygoribatula sp3 & $15.75 \mathrm{D}$ & 18.53D \\
\hline Zygoribatula sp4 & $0.95 \mathrm{R}$ & $1.25 \mathrm{R}$ \\
\hline \multicolumn{3}{|l|}{ Scheloribatidae Grandjean } \\
\hline Scheloribates sp1 & - & - \\
\hline Scheloribates sp2 & $0.16 \mathrm{R}$ & $0.66 \mathrm{R}$ \\
\hline Scheloribates sp3 & - & - \\
\hline Scheloribatidae (one species) & - & $0.01 \mathrm{R}$ \\
\hline \multicolumn{3}{|l|}{ Tectocepheidae Grandjean } \\
\hline Tectocepheus sp. & $0.64 \mathrm{R}$ & 6.351 \\
\hline Juveniles of Oribatida† & 55.50 & 49.62 \\
\hline Juveniles of Sarcoptiformest & 55.50 & 49.62 \\
\hline Order Trombidiformes Reuter & 24.38D & $12.74 \mathrm{D}$ \\
\hline Suborder Prostigmata Kramer & $24.38 \mathrm{D}$ & 12.74D \\
\hline \multicolumn{3}{|l|}{ Anystidae Oudemans } \\
\hline Anystidae (one species) & - & - \\
\hline \multicolumn{3}{|l|}{ Bdellidae Dugès } \\
\hline Bdella sp. & - & - \\
\hline Bdellodes sp. & - & $0.01 R$ \\
\hline \multicolumn{3}{|l|}{ Camerobiidae Southcott } \\
\hline Neophyllobius sp. & - & - \\
\hline \multicolumn{3}{|l|}{ Cheyletidae Leach } \\
\hline Cheletogenes sp. & - & - \\
\hline Hemicheyletia sp. & - & $0.03 R$ \\
\hline \multicolumn{3}{|l|}{ Cunaxidae Thor } \\
\hline Cunaxoides croceus (Koch) ${ }^{1}$ & - & - \\
\hline Cunaxoides paracroceus Sionti \& Papadoulis ${ }^{1}$ & $0.01 \mathrm{R}$ & $0.01 R$ \\
\hline Pulaeus subterraneus (Berlese) ${ }^{1}$ & - & - \\
\hline \multicolumn{3}{|l|}{ Ereynetidae Oudemans } \\
\hline Ereynetidae (one species) & - & $0.04 \mathrm{R}$ \\
\hline \multicolumn{3}{|l|}{ Eriophyidae Nalepa } \\
\hline Aceria medicaginis (Keifer)* & - & + \\
\hline \multicolumn{3}{|l|}{ Erythraeidae Robineau-Desvoidy } \\
\hline Abrolophus sp. & $0.01 \mathrm{R}$ & - \\
\hline Curteria sp. & - & - \\
\hline \multicolumn{3}{|l|}{ Eupalopsellidae Willmann } \\
\hline Eupalopsellus sp. & - & - \\
\hline Eupodidae Koch & & \\
\hline Eupodidae (species A) & $0.02 \mathrm{R}$ & $0.07 R$ \\
\hline Eupodidae (species B) & - & $0.01 \mathrm{R}$ \\
\hline Eupodidae (species C) & - & $0.05 R$ \\
\hline
\end{tabular}




\begin{tabular}{|c|c|c|}
\hline \multirow{2}{*}{ TAXA } & \multicolumn{2}{|c|}{ Relative abundance (\%) } \\
\hline & Foliage & Litter \\
\hline \multicolumn{3}{|l|}{ Iolinidae André } \\
\hline Pronematus sp1 & - & - \\
\hline Pronematus sp2 & - & - \\
\hline \multicolumn{3}{|l|}{ Pyemotidae Oudemans } \\
\hline Pyemotes sp. & - & - \\
\hline \multicolumn{3}{|l|}{ Pygmephoridae Cross } \\
\hline Acinogaster sp. & - & - \\
\hline Pygmephorus sp1 & - & $0.05 R$ \\
\hline Pygmephorus sp2 & - & $0.02 R$ \\
\hline Pygmephorus sp3 & - & $0.02 R$ \\
\hline Pygmephorus sp4 & - & - \\
\hline Pygmephorus sp5 & $0.01 R$ & - \\
\hline Pygmephorus sp6 & $0.03 R$ & $0.14 \mathrm{R}$ \\
\hline Pygmephorus sp7 & - & $0.02 \mathrm{R}$ \\
\hline Siteroptes sp. & $0.05 \mathrm{R}$ & $0.03 R$ \\
\hline \multicolumn{3}{|l|}{ Rhagidiidae Oudemans } \\
\hline Rhagidiidae (one species) & - & $0.01 R$ \\
\hline \multicolumn{3}{|l|}{ Raphignathidae Kramer } \\
\hline Raphignathus sp. & - & $0.01 R$ \\
\hline \multicolumn{3}{|l|}{ Scutacaridae Oudemans } \\
\hline Imparipes sp. & - & - \\
\hline Scutacarus sp. & - & - \\
\hline \multicolumn{3}{|l|}{ Stigmaeidae Oudemans } \\
\hline Eustigmaeus jiangxiensis Hu. Chen \& Huang ${ }^{1}$ & - & $0.03 R$ \\
\hline Eustigmaeus sp. & $0.01 \mathrm{R}$ & - \\
\hline Stigmaeus sp. & - & - \\
\hline \multicolumn{3}{|l|}{ Tarsonemidae Kramer } \\
\hline Neotarsonemoides sp. & $0.18 \mathrm{R}$ & $0.84 \mathrm{R}$ \\
\hline Steneotarsonemus konoi Smiley \& Emmanouel & $0.15 \mathrm{R}$ & $0.10 \mathrm{R}$ \\
\hline Tarsonemus sp1 & $2.43 R$ & $3.72 \mathrm{R}$ \\
\hline Tarsonemus sp2 & $1.21 \mathrm{R}$ & $1.04 \mathrm{R}$ \\
\hline Tarsonemus confusus Ewing & $0.32 \mathrm{R}$ & $0.05 R$ \\
\hline Tarsonemus fusarii Cooreman & $0.03 R$ & $0.32 \mathrm{R}$ \\
\hline Tarsonemus lacustris Schaarschmidt & 9.651 & $1.18 \mathrm{R}$ \\
\hline Tarsonemus talpae Schaarschmidt & $0.11 R$ & $0.36 R$ \\
\hline Tarsonemus waitei Banks & $2.64 \mathrm{R}$ & $0.56 \mathrm{R}$ \\
\hline Xenotarsonemus belemnitoides (Weis-Fogh) & $1.00 \mathrm{R}$ & $0.77 \mathrm{R}$ \\
\hline \multicolumn{3}{|l|}{ Tenuipalpidae Berlese } \\
\hline Brevipalpus sp. & $0.04 \mathrm{R}$ & $0.01 R$ \\
\hline \multicolumn{3}{|l|}{ Tetranychidae Donnadieu } \\
\hline Bryobia praetiosa Koch* & - & - \\
\hline Bryobia sp.* & - & + \\
\hline Petrobiini sp.* & - & + \\
\hline Tetranychini sp.* & - & + \\
\hline \multicolumn{3}{|l|}{ Triophtydeidae André } \\
\hline Triophtydeus sp. & $0.02 \mathrm{R}$ & $0.01 R$ \\
\hline \multicolumn{3}{|l|}{ Trombiculidae Ewing } \\
\hline Trombiculidae (one species) & - & - \\
\hline \multicolumn{3}{|l|}{ Trombidiidae Leach } \\
\hline Trombidiidae (one species) & $0.01 \mathrm{R}$ & - \\
\hline \multicolumn{3}{|l|}{ Tydeidae Kramer } \\
\hline Lorryia ferula Baker & $0.05 R$ & - \\
\hline Lorryia nesziyyonensis (Gerson) ${ }^{1}$ & - & - \\
\hline Lorryia sp. & $0.13 R$ & $0.17 R$ \\
\hline Tydeus kochi Oudemans & $4.86 \mathrm{R}$ & $1.81 \mathrm{R}$ \\
\hline Juveniles of Prostigmata† & 1.41 & 1.25 \\
\hline Juveniles of Trombidiformest & 1.41 & 1.25 \\
\hline Total number of samples & 240 & 288 \\
\hline Total number of individuals & 10,938 & 12,325 \\
\hline Total number of species & 50 & 68 \\
\hline
\end{tabular}




\begin{tabular}{lc}
\hline & Relative abundance (\%) \\
\cline { 2 - 2 } TAXA & Foliage \\
Number of common species in foliage of fields A and C: 37 \\
Number of common species in foliage of fields B and C: 41 \\
Number of common species in litter of fields A and C: 61 \\
\hline D: Dominant (> 10\%), I: Influent (5\%-10\%) and R: Recedent (<5\%) \\
'New records for the mite fauna of Medicago sativa L. ssp. sativa of Greece \\
† juveniles of mite Orders and suborders are not considered as separate taxa and are not consequently classified as \\
dominant, influent or recedent \\
*not counted in the calculation of population fluctuation, population density, Sobs. Jackknife 1 estimator and \\
Shannon-Weaver index ( $H^{\prime}$ ) of diversity. Instead of relative abundance (\%), results are presented as "+" and "-" for \\
these mites indicating their presence or absence respectively \\
Field A: Unsprayed alfalfa field managed with monthly cuttings \\
Field B: Unsprayed alfalfa field managed with bimonthly cuttings \\
Field C: Bifenthrin-sprayed alfalfa field managed with monthly cuttings
\end{tabular}

et al., 2008). The non-parametric estimator of species richness, Jackknife 1, was used (Krebs, 1999; Colwell, 2013) as well as Shannon index $\left(H^{\prime}\right)$ for the calculation of species diversity of mites (Hutcheson, 1970; Magurran, 2004). The spatial distribution of common and influent mite species was estimated with Taylor's power law and Iwao's regression of patchiness (Badieritakis et al., 2014).

GLM of SAS JMP 7.0.1. statistical package at $a=0.05$ (after a log $(\mathrm{x}+1)$ transformation of the dataset) was used to compare the population density of mites between field $C$ and fields $\mathrm{A}$ and $\mathrm{B}$. The population density was expressed as the mean number of individuals per quadrat. The dry weight of foliage and litter samples collected was also compared between field $C$ and the other two fields by using GLM after a $\log (\mathrm{x})$ transformation of the data.

\section{Results}

\section{Dry weight comparison}

The mean dry weight of foliage samples of field $C$ was $7.70 \mathrm{~g}( \pm 1.37 \mathrm{~g})$ without being significantly different from the respective dry weight calculated for field A (d. $f .=1$, $\left.X^{2}=0.1168, p=0.7325\right)$ and field $B\left(d . f .=1, X^{2}=\right.$ $0.0286, p=0.8657)$. In addition, the mean dry weight of litter samples in field $C$ was $4.09 \mathrm{~g}$ $( \pm 0.40 \mathrm{~g})$ revealing no significant difference with the respective dry weight calculated for field $\mathrm{A}\left(d . f .=1, \chi^{2}=0.0369, p=0.8475\right)$ and field B ( $\left.d . f .=1, X^{2}=1.3887, p=0.2490\right)$. Therefore, no significant differences were found regarding the plant biomass of field $\mathrm{C}$ compared to that of the other two fields.

\section{Mite fauna and relative abundance}

In total, 23,263 individuals of mites (adults and juveniles) were collected from the foliage and litter samples collected from field C between 2008-2010. In particular, 50 and 68 species and morphospecies were respectively recorded from foliage and litter samples belonging to Mesostigmata, Sarcoptiformes and Trombidiformes, many of which were common with those found in fields $A$ and $B$ (Table 1). Many species were also common between field $C$ and fields $A$ and $B$. A new species record for the mite fauna of alfalfa of Greece was that of the phytoseiid, $\mathrm{Ne}$ oseiulus aristotelisi Papadoulis, Emmanouel and Kapaxidi. Sarcoptiformes and Trombidiformes were the most abundant mite Orders in both foliage and litter samples. Among Sarcoptiformes the family Oribatulidae recorded high relative abundance.

\section{Population fluctuation}

Between 2008-2010 the population of total Acari hosted in the foliage of field C (Fig. 1a) presented high density in spring and summer. A similar seasonal pattern of population fluctuation was detected in the case of Oribatida (Fig. 1b). However, both Prostigmata and Mesostigmata had low population densities during the two-year study. In the 
case of prostigmatic mites, their population density peaked in April 2009 (Fig. 1b).

In comparison to the findings in foliage samples, the population fluctuation of mites in litter revealed high population densities of mites in summer and autumn in both years (Fig. 1c). The same seasonal pattern was detected in the case of Oribatida, although Prostigmata and Mesostigmata showed lower population densities, almost zero during long time periods (months) (Fig. 1d).

\section{Population density}

Taking into account the results presented by Badieritakis et al. (2014) and Table 2 of the present study, significant higher population density of mites was detected in the foliage and litter samples of field B, when compared to field C, except for Prostigmata, which were more abundant in field C. On the other hand, the population density of mites was similar in the foliage of fields $C$ and $A$, except for mesostigmatic mites, whose density was lower in field $C$. In the case of litter, oribatid and prostigmatic mites recorded higher population density in field $C$ than in field $A$, although that of total Acari and mesostigmatic mites was similar between these two fields.

\section{Species richness and diversity}

Litter hosted more mite species than foliage. Prostigmata were generally more species abundant when compared to other taxa. Taking into account Jackknife 1 estimator and its confidence limits calculated for the mite fauna in all fields, it seems that field $C$ hosted similar number of mite species with field B in foliage and litter, but lower number of species in foliage when compared to field A. However, both fields, A and $C$, hosted similar number of mite species in litter. On the other hand, field $C$ shared also the same diversity of mites with fields $A$ and $B$ in foliage and litter (Table 3).

\section{Spatial distribution}

Only Zygoribatula sp3 was dominant in foliage and litter and Zygoribatula sp1 was influent in litter of all fields (Table 4). These morphospecies had an aggregated pattern of spatial distribution $(b>1)$. Since parameter $a$ of Iwao's regression of patchiness was not significantly different from zero, we can also assume that the basic component of mite populations could have been one individual per quadrat. Moreover, Taylor's power law had a better fit to the data than Iwao's regression of patchiness (correlation coefficients $r$ ).

\section{Discussion}

The findings of the present study stressed that the bifethrin-sprayed field hosted many common mite species with the two unsprayed fields. The high relative abundance of oribatid mites in the bifenthrin-sprayed field could be attributed to the previous maize crop. Maize has been reported to host Oribatida in New York by Minor and Cianciolo (2007). Neoseiulus aristotelisi, a new phytoseiid species, was first reported in Greece by Papadoulis et al. (2009) on Oryza sativa (Poaceae) in Macedonia, Greece. However, no other information is available on the preferred habitats of this species.

The population fluctuation of total Acari in foliage of the bifenthrin-sprayed field was similar with that in the unsprayed fields (Badieritakis et al., 2014). Due to their high relative abundance among total Acari in foliage, a similar population fluctuation of oribatid mites was also observed. The similar population fluctuation of Oribatida could be attributed to their high relative abundance among total Acari. Since Zygoribatula was dominant in foliage and litter of the bifenthrin-sprayed field, as it happened in the unsprayed, managed with different number of cuttings, fields (Badieritakis et al., 2014), we speculate that the high densities of oribatid mites in summer represented this genus. The population fluctuation of prostigmatic and mesostigmatic mites in the foliage of the bifenthrin-sprayed field was more or less similar with that in the unsprayed fields. Hence, the findings demonstrate that the 


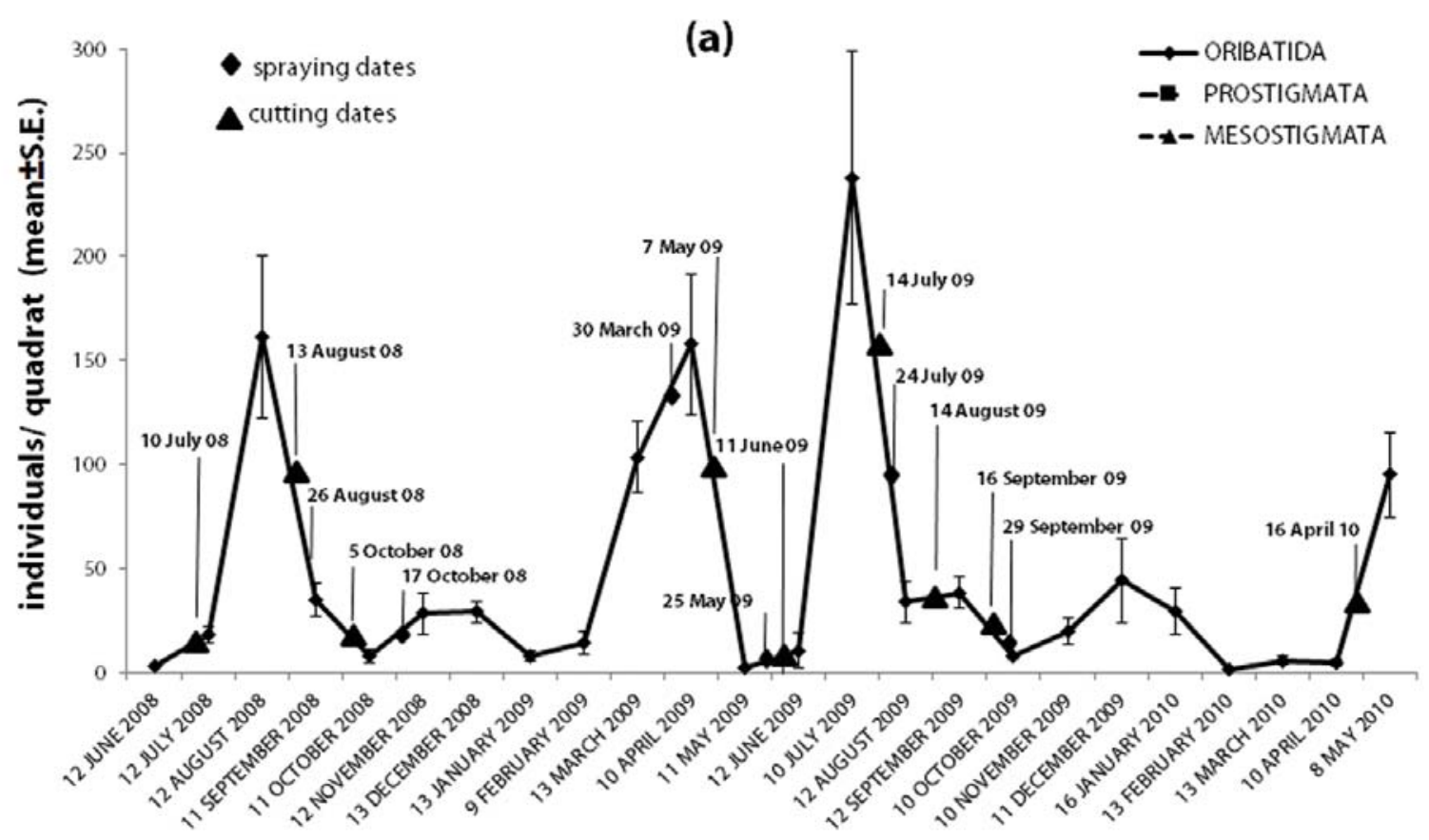

Sampling dates

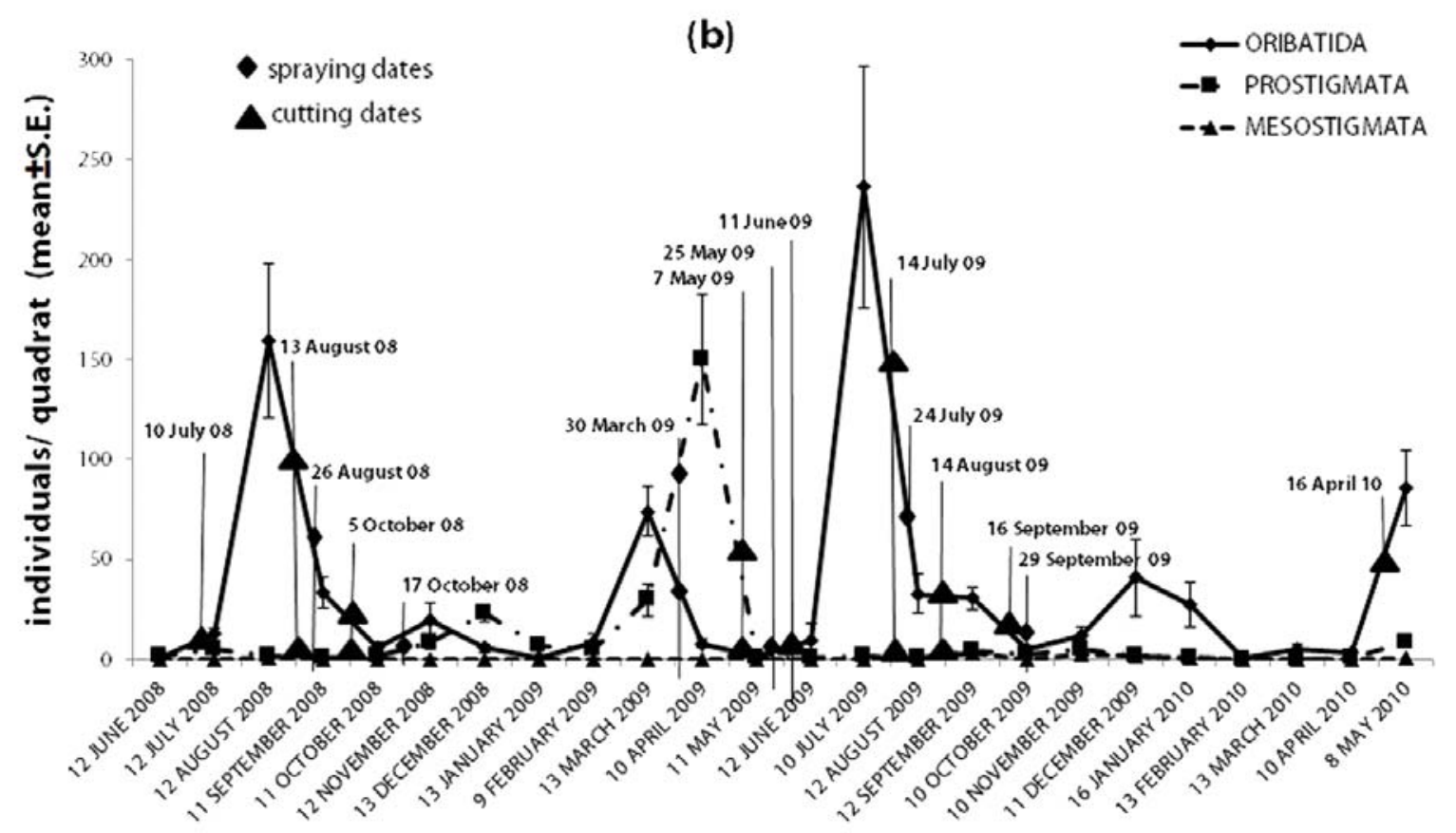

Sampling dates

Figure 1. (a) Population fluctuation of total Acari and (b) main mite taxa, in foliage of a bifenthrin-sprayed alfalfa field in Kopais Valley (Central Greece) between 2008-2010. 


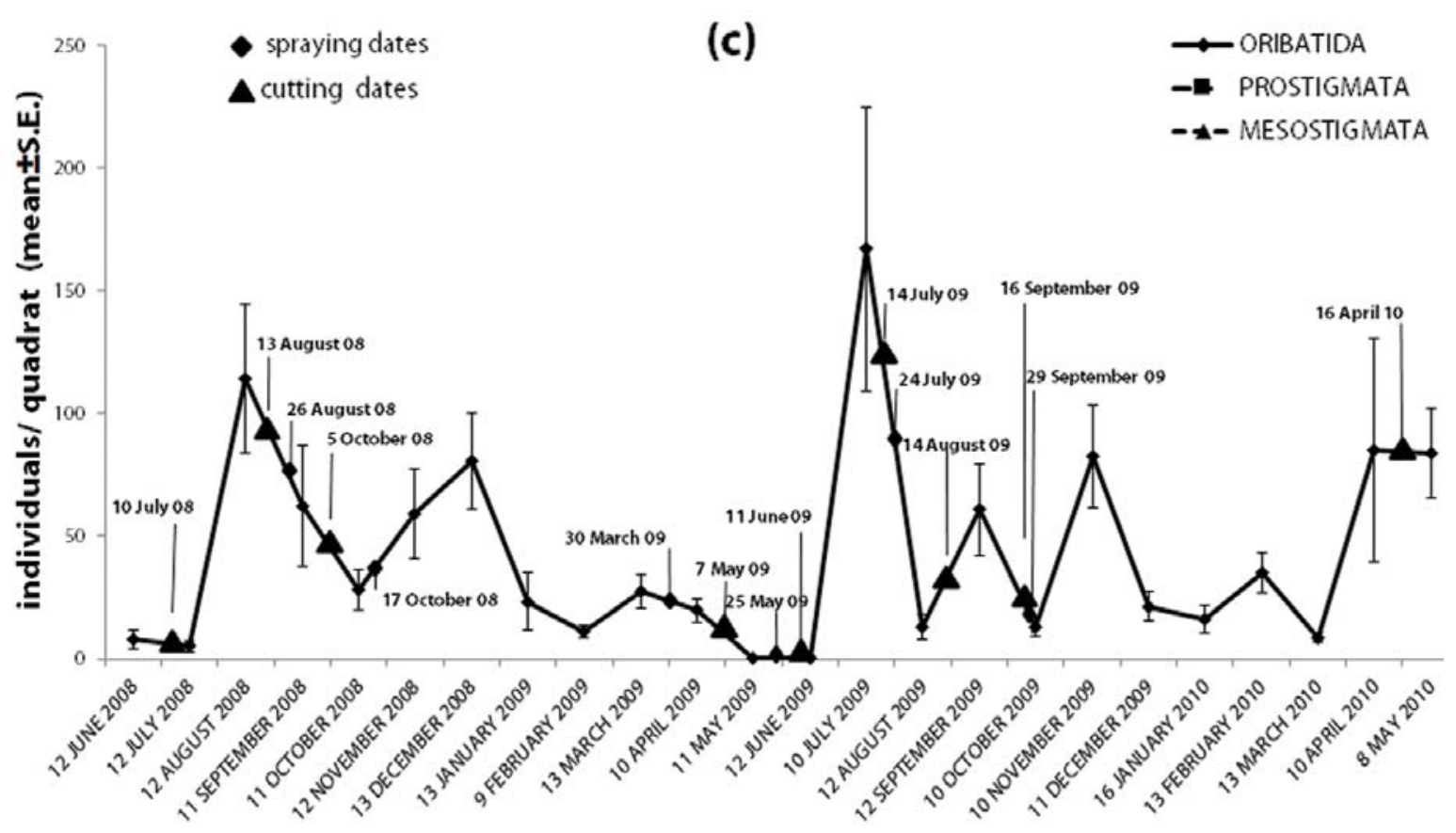

Sampling dates

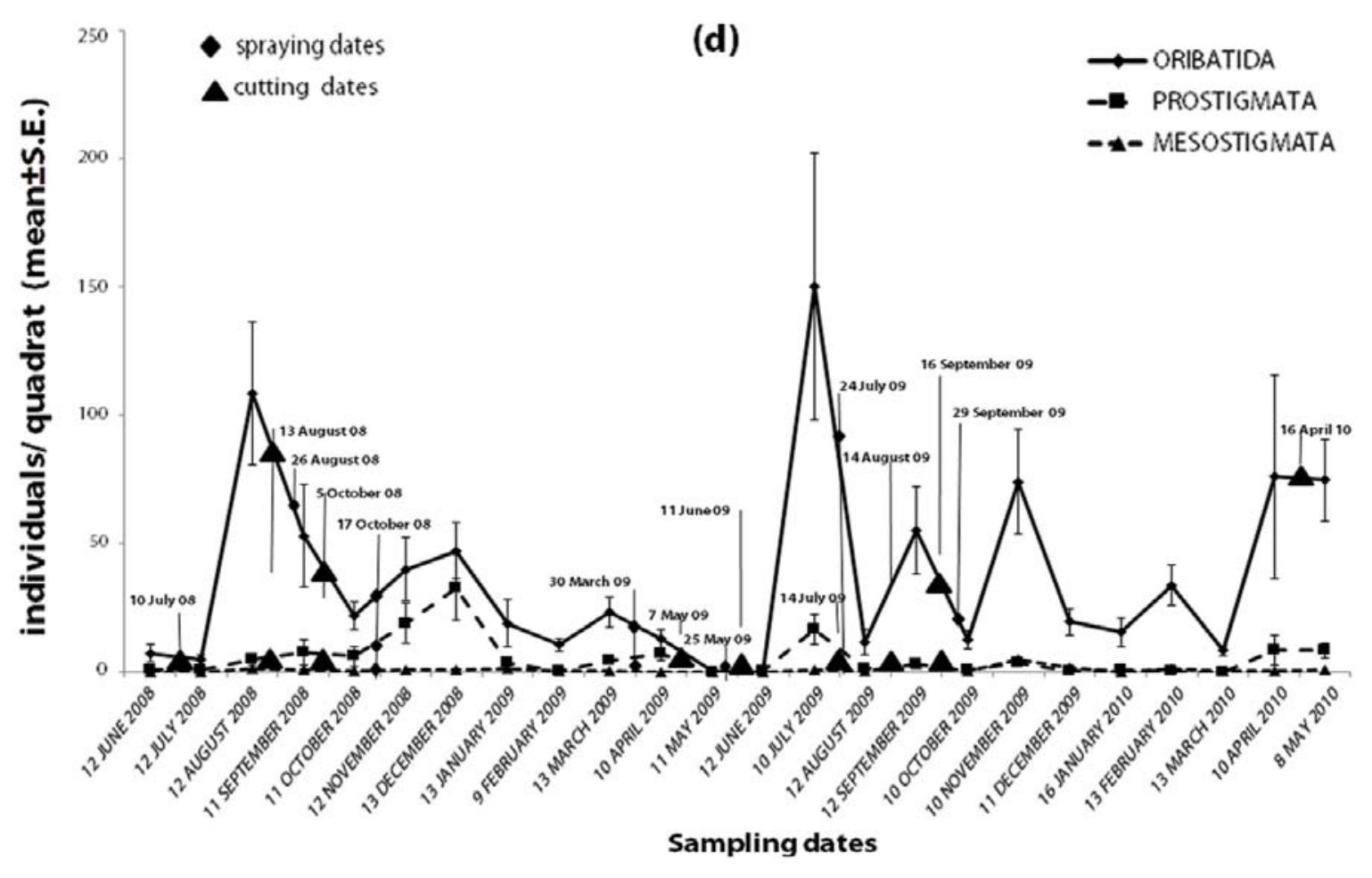

Figure 1. (c) Population fluctuation of total Acari (a) and (d) main mite taxa, in litter of a bifenthrin-sprayed alfalfa field in Kopais Valley (Central Greece) between 2008-2010. 
Table 2. Population density (mean \pm S.E.) of total Acari, order Mesostigmata, suborder Oribatida (Acari: Sarcoptiformes) and suborder Prostigmata (Acari: Trombidiformes) found in the foliage and litter of alfalfa fields receiving different management between 2008-2010 in Kopais Valley, Central Greece (GLM, $a=0.05)$ for the hypothesis of similar population density .

\begin{tabular}{l|c|c|c|c}
\hline Habitat & Taxa & Field C & Field A & Field B \\
\hline \multirow{4}{*}{ Foliage } & Total Acari & $45.58 \pm 5.28$ & $X^{2}=0.1889, p=0.6638$ & $X^{2}=14.1997, p=0.0002^{*}$ \\
& Mesostigmata & $0.4125 \pm 0.0824$ & $X^{2}=4.3212, p=0.0376^{*}$ & $X^{2}=13.7020, p=0.0002^{*}$ \\
& Oribatida & $34.18 \pm 4.79$ & $X^{2}=0.3834, p=0.5358$ & $X^{2}=31.1286, p<0.0001^{*}$ \\
& Prostigmata & $10.97 \pm 2.36$ & $X^{2}=0.2176, p=0.6408$ & $X^{2}=7.9220, p=0.0049^{*}$ \\
& Total Acari & $42.79 \pm 4.55$ & $X^{2}=3.2959, p=0.0695$ & $X^{2}=34.7409, p<0.0001^{*}$ \\
& Mesostigmata & $0.77 \pm 0.12$ & $X^{2}=1.5526, p=0.2128$ & $X^{2}=21.7506, p<0.0001^{*}$ \\
& Oribatida & $36.57 \pm 3.99$ & $X^{2}=8.6078, p=0.0033^{*}$ & $X^{2}=40.0851, p<0.0001^{*}$ \\
& Prostigmata & $5.39 \pm 0.88$ & $X^{2}=4.0045, p=0.0454^{*}$ & $X^{2}=0.5156, p=0.4727$ \\
\hline
\end{tabular}

* significant difference

Field A: Unsprayed alfalfa field managed with monthly cuttings

Field B: Unsprayed alfalfa field managed with bimonthly cuttings

Field C: Bifenthrin-sprayed alfalfa field managed with monthly cuttings

Table 3. Number of species observed (Sobs), estimation of species richness (Jackknife 1) and diversity (Shannon-Weaver index, $H^{\prime}$ ) of total Acari, order Mesostigmata, suborder Oribatida (Acari: Sarcoptiformes) and suborder Prostigmata (Acari: Trombidiformes) in foliage and litter of alfalfa fields receiving different management in Kopais Valley, Central Greece, between 2008-2010 for the hypothesis of similar species richness and diversity $(a=0.05)$.

\begin{tabular}{|c|c|c|c|c|c|c|}
\hline \multirow{2}{*}{ Habitat } & \multirow{2}{*}{ Taxa } & \multirow{2}{*}{ Sobs } & \multirow{2}{*}{$\begin{array}{l}\text { Jackknife } 1 \text { esti- } \\
\text { mator }(95 \% \mathrm{CL})^{2}\end{array}$} & \multicolumn{3}{|c|}{ Shannon - Wiener index $\left(H^{\prime}\right)$} \\
\hline & & & & Field C & Field $A^{3}$ & Field $B^{3}$ \\
\hline \multirow{4}{*}{ Foliage } & Total Acari ${ }^{1}$ & 50 & $67.93(60-76)$ & 2.06 & d.f. $=4676, t=0.00286$ & d.f. $=4676, t=0.3171$ \\
\hline & Mesostigmata & 9 & $13.98(10-18)$ & 0.79 & d.f. $=62, t=0.1907$ & d.f. $=62, t=0.2515$ \\
\hline & Oribatida & 15 & $18.98(15-23)$ & 1.74 & d.f. $=2133, t=0.01735$ & d.f. $=2132, t=0.0024$ \\
\hline & Prostigmata' & 23 & $28.98(24-34)$ & 1.35 & d.f. $=2481, t=0.0889$ & d.f. $=2482, t=0.1497$ \\
\hline \multirow{4}{*}{ Litter } & Total Acari ${ }^{1}$ & 64 & $86.93(77-97)$ & 2.35 & d.f. $=5980, t=0.0927$ & d.f. $=5980, t=0.2809$ \\
\hline & Mesostigmata & 11 & $20.98(16-26)$ & 1.50 & d.f. $=145, t=0.0977$ & d.f. $=145, t=0.2041$ \\
\hline & Oribatida & 20 & $22.99(20-26)$ & 2.21 & d.f. $=4419, \mathrm{t}=0.1332$ & d.f. $=4419, t=0.1581$ \\
\hline & Prostigmata' & 30 & $39.97(34-46)$ & 2.00 & d.f. $=1401, t=0.2135$ & d.f. $=1401, t=0.2566$ \\
\hline
\end{tabular}

${ }^{1}$ species belonging to Eriophyidae and Tetranychidae are not included

2 confidence limits are rounded

${ }^{3}$ degrees of freedom (d.f.) and t calculated according to Hutcheson's method for the comparison of field $C$ with fields $A$ and $B$

Field A: Unsprayed alfalfa field managed with monthly cuttings

Field B: Unsprayed alfalfa field managed with bimonthly cuttings

Field C: Bifenthrin-sprayed alfalfa field managed with monthly cuttings

seasonal fluctuation of mites in foliage is not affected by agricultural practices, such as pesticide application and different number of cuttings. However, this was not the case for mites found in litter; it seems that no seasonal pattern of population fluctuation of mites in litter can be designated for alfalfa. The population densities of prostig- matic and mesostigmatic mites in litter and foliage were very low, almost zero, for many months. This could be possibly attributed to the intensive management in the sprayed field (cuttings and pesticide applications), which did not help the populations of these taxa to restore.

Mite population density in the bifen- 
Table 4. Parameters of Taylor's power law and Iwao's patchiness regression of mite species in foliage and litter, which were common and concurrently dominant or influent in alfalfa fields receiving different management during 2008 - 2010 in Kopais Valley (Central Greece) for the hypothesis of aggregated pattern of spatial distribution.

\begin{tabular}{lcccccccc}
\hline \multirow{2}{*}{ Habitat } & Mites & $n^{1}$ & \multicolumn{3}{c}{ Taylor's power law } & \multicolumn{2}{c}{ Iwao's patchiness regression } \\
\cline { 3 - 9 } Foliage & \begin{tabular}{c} 
Zygoribatula sp3 \\
\cline { 3 - 8 }
\end{tabular} & 22 & $0.42 \pm 0.07^{*}$ & $1.77 \pm 0.08^{*}$ & $0.98^{*}$ & $5.32 \pm 4.35$ & $1.78 \pm 0.26^{*}$ & $0.84^{*}$ \\
\cline { 2 - 9 } & $\begin{array}{c}\text { Zygoribatula sp1 } \\
\text { Litter }\end{array}$ & 21 & $0.52 \pm 0.04^{*}$ & $1.59 \pm 0.08^{*}$ & $0.98^{*}$ & $1.02 \pm 0.77$ & $2.22 \pm 0.22^{*}$ & $0.91^{*}$ \\
\hline $\begin{array}{c}\text { (influent) } \\
\text { Zygoribatula sp3 } \\
\text { (dominant) }\end{array}$ & 23 & $0.43 \pm 0.08^{*}$ & $1.66 \pm 0.09^{*}$ & $0.97^{*}$ & $0.59 \pm 1.56$ & $2.09 \pm 0.14^{*}$ & $0.95^{*}$ \\
\hline
\end{tabular}

1 Number of mean - variance and mean - mean crowding pairs used in the regressions

$2,3,4$ Parameters of Taylor's power law. Parameters log $(a)$ and $b$ ( \pm S.E.) and correlation coefficient $r$

$5,6,7$ Parameters of Iwao's patchiness regression. Parameters $a$ and $b$ ( \pm S.E.) and correlation coefficient $r$

* significant difference of parameters $\log (a), a$ and $r$ from 0 and parameter $b$ from 1 in both models $(a=0.05, t$ - test) at $n-2$ degrees of freedom

Different management: bifenthrin-sprayed + monthly cuttings (current study); unsprayed + monthly cuttings; unsprayed + bimonthly cuttings

thrin-sprayed field was lower compared to the unsprayed field with half number of cuttings, except for the density of prostigmatic mites in litter and foliage, which were lower in the unsprayed field. By contrast, the mite population density did not differ in the case of the bifenthrin-sprayed and the unsprayed field managed with the same number of cuttings, except for mesostigmatic mites in foliage and oribatid and prostigmatic mites in litter. Agricultural practices, such as the application of pesticides can affect the mite communities of soil, particularly Mesostigmata whose density can be significantly reduced in conventional fields in comparison to uncultivated sites (Bedano and Ruf, 2007). In addition, many predatory arthropods tend to find refugia in soil or litter of grasslands after the application of pesticides (Roberts et al., 2011), which could explain the lower population density of mesostigmatic mites in the foliage of the bifenthrin-sprayed field. In the case of oribatid mites the use of agrochemicals and intensive agricultural practices may reduce the organic matter of soil leading to lower population densities which cannot easily recover in the short term (Bedano et al., 2006). On the other hand, Clapperton et al. (2002) concluded that prostigmatic mites are abundant in disturbed sites (heavily grazed prairies) in com- parison to other mite taxa of soil.

In terms of species richness, the bifenthrin-sprayed field was poor in species in foliage when compared to the unsprayed field with the same number of cuttings (Badieritakis et al., 2014). This result is in accordance with the findings of Koehler (1999), that species richness of mites is negatively affected by agricultural practices.

The diversity of mites was similar between the bifenthrin-sprayed field and the unsprayed fields. However, the diversity of mites was generally higher in the field with monthly cuttings than that in field with bimonthly cuttings (Badieritakis et al., 2014). The diversity of mesostigmatic mites is reduced in conventional fields when compared to sites which are not disturbed (Bedano and Ruf, 2007). On the other hand, the diversity of oribatid mites is usually negatively affected by the intensity of agricultural practices (Minor and Cianciolo, 2007). In the case of the bifenthrin-sprayed field, the increased disturbance seems not to have affected the diversity of prostigmatic and oribatid mites, possibly due to an increase of relative abundance of mite species that balanced the decrease in species richness.

An aggregated pattern of spatial distribution of common and dominant or influent mites (Zygoribatula sp1 and Zygoribatula 
sp3) was confirmed ( $b>1$ in Taylor's power law and Iwao's regression of patchiness). In addition, Taylor's power law fitted better to the data when compared to Iwao's regression of patchiness. We also assume that Zygoribatula sp3 did not form colonies (parameter $a$ of Iwao's regression of patchiness not significantly different from zero) as it happened in many cases of the unsprayed fields managed with different number of cuttings (Badieritakis et al., 2014).

Our results show that an occasionally sprayed with an acaricide-insecticide alfalfa hay field hosted a rich mite fauna similar to that of two adjacent unsprayed alfalfa hay fields. The seasonal fluctuation of mites was also similar in all fields, although similarity in species richness mainly occurred between the sprayed field and the unsprayed field with half number of cuttings. Some differentiations in population density of mites also occurred between the sprayed field and the unsprayed ones, possibly due to the extra disturbance in the sprayed field. The spatial distribution of mites was aggregated in all fields. Our results indicate that spraying alfalfa with a pesticide slightly affects the mite populations in foliage and litter. We have to stress, however, that more replicates of fields are needed to be sure about the impact of the spraying with pesticides on mite communities.

The authors would like to express their gratitude towards the Farm Unit of the Agricultural University of Athens for their help with the experiments in the Kopais region as well as towards the Laboratory of Plant Breeding and Biometry of the same University for providing SAS JMP 7.0.1. statistical package. The authors are also grateful to Professor George Th. Papadoulis for his help with the identification of $\mathrm{Cu}$ naxidae and Phytoseiidae and to Dr Eleftheria $V$. Kapaxidi for identifying E. jiangxiensis. This study was funded by the State Scholarships Foundation of Greece.

\section{Literature cited}

Alatawi, F., Nechols, J.R. and Margolies, D.C. 2011. Spatial distribution of predators and prey affect biological control of twospotted spider mites by Phytoseiulus persimilis in greenhouses. Biological Control, 56(1):36-42.

Andrés, P. and Mateos, E. 2006. Soil mesofaunal responses to post-mining restoration treatments. Applied Soil Ecology, 33:67-78.

Badieritakis, E.G., Fantinou, A.A. and Emmanouel, N.G. 2014. A qualitative and quantitative study of mites in similar alfalfa fields in Greece. Experimental and Applied Acarology, 62(2): 195-214.

Bedano, J.C., Cantú, M.P. and Doucet, M.E. 2006. Influence of three different land management practices on soil mite (Arachnida: Acari) density in relation to a natural soil. Applied Soil Ecology, 32:293-304.

Bedano, J.C. and Ruf, A. 2007. Soil predatory mite communities (Acari: Gamasina) in agroecosystems of Central Argentina. Applied Soil Ecology, 36:22-31.

Bosch-Serra, A.D., Padró, R., Boixadera-Bosch, R.R., Orobitg, J. and Yagüe, M.R. 2014. Tillage and slurry over-fertilization affect oribatid mite communities in a semiarid Mediterranean environment. Applied Soil Ecology, 84:124-139.

Clapperton, M.J., Kanashiro, D.A. and Behan-Pelletier, V.M. 2002. Changes in abundance and diversity of microarthropods associated with fescue prairie grazing regimes. Pedobiologia, 46:496-511

Colwell, R.K. 2013. EstimateS 9.0 User's Guide. Statistical estimation of species richness and shared species for samples. http://viceroy.eeb.uconn. edu/estimates/EstimateSPages/EstSUsersGuide/EstimateSUsersGuide.htm Accessed 13 May 2015.

Hellenic Statistical Authority. 2019. http://www.statistics.gr/el/statistics/-/publication/SPG06/-. Accessed 24.06.2019.

Hutcheson, K. 1970. A test for comparing diversities based on the Shannon formula. Journal of Theoretical Biology, 29(1):151-154.

Koehler, H.H. 1999. Predatory mites (Gamasina, Mesostigmata). In Invertebrate Biodiversity as Bioindicators of Sustainable Landscapes - Practical Use of Invertebrates to Assess Sustainable Land Use. Elsevier B.V., p. 395-410.

Krantz, G.W. 2009. Habits and Habitats. In A Manual of Acarology. $3^{\text {rd }}$ Edition. Texas Tech University Press. Lubbock, Texas, p. 64-80.

Krebs, C.J. 1999. Ecological methodology. $2^{\text {nd }}$ Edition. Addison-Wesley Educational Publishers Inc., $620 \mathrm{p}$.

Magurran, A.E. 2004. Measuring biological diversity. Blackwell Science Ltd, 215 p.

Minor, M.A. and Cianciolo, J.M. 2007. Diversity of soil 
mites (Acari: Oribatida, Mesostigmata) along a gradient of land use types in New York. Applied Soil Ecology, 35: 140-153.

Palyvos, N.E., Emmanouel, N.G. and Saitanis, C.J. 2008. Mites associated with stored products in Greece. Experimental and Applied Acarology, 44(3):213-226.

Papadoulis, G.Th., Emmanouel, N.G. and Kapaxidi, E.V. 2009. Phytoseiidae of Greece and Cyprus (Acari: Mesostigmata). Indira Publishing House, 200 p.

Roberts, J.M.K., Weeks, A.R., Hoffmann, A.A., Paul, A. and Umina, P.A. 2011. Does Bdellodes lapidaria (Acari: Bdellidae) have a role in biological control of the springtail pest, Sminthurus viridis (Collembola: Sminthuridae) in south-eastern Australia? Biological Control, 58(3):222-229.

Sabelis, M.W. and van Rijn, P.C.J. 1997. Predation by Insects and Mites. In Thrips as Crop Pests ( $T$.
Lewis, Ed.), CAB-International, London, p. 259354.

Schneider, K., Migge, S., Norton, R.A., Scheu, S., Langel, R., Reineking, A. and Maraun, M. 2004. Trophic niche differentiation in soil microarthropods (Oribatida, Acari): evidence from stable isotope ratios $\left({ }^{15} \mathrm{~N} /{ }^{14} \mathrm{~N}\right)$. Soil Biology and Biochemistry, 36:1769-1774.

Wissuwa, J., Salamon, J.-A. and Frank, T. 2012. Effects of habitat age and plant species on predatory mites (Acari, Mesostigmata) in grassy arable fallows in Eastern Austria. Soil Biology and Biochemistry, 50:96-107.

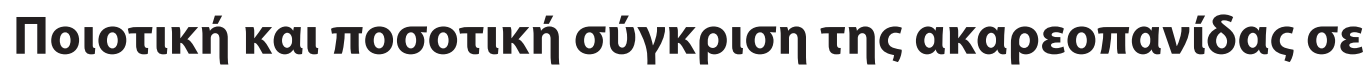

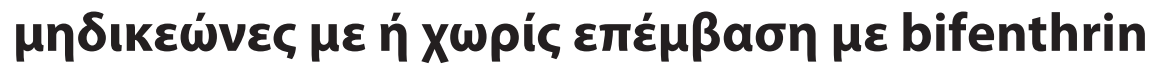

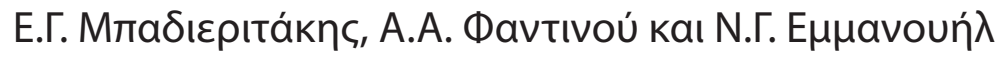

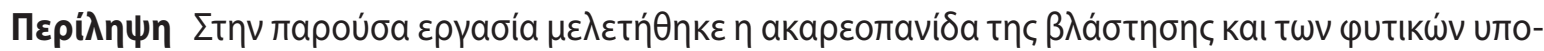

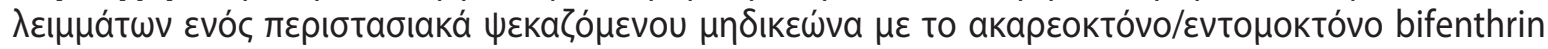

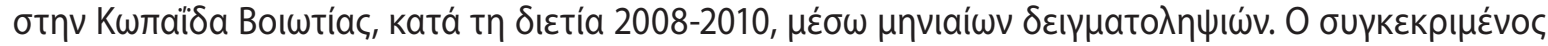

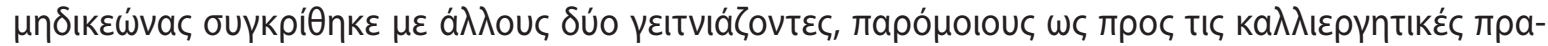

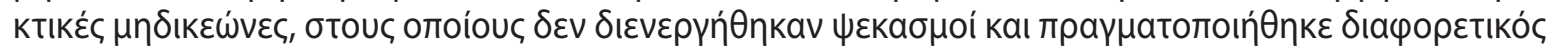

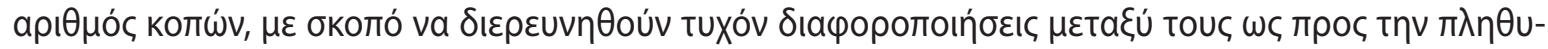

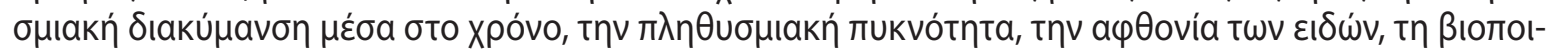
кı

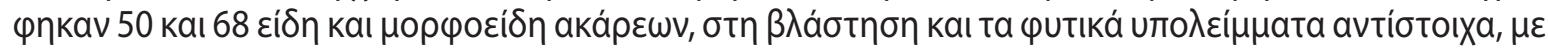

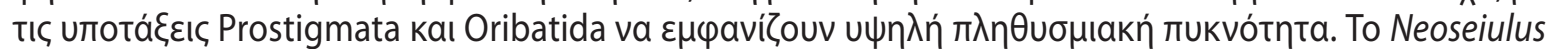

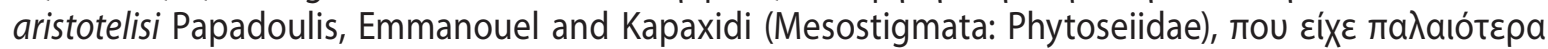

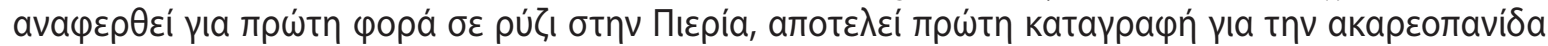

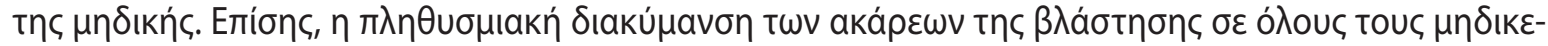

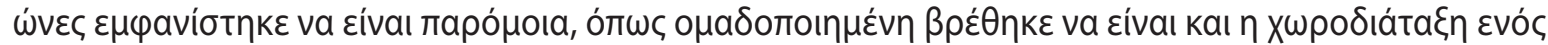

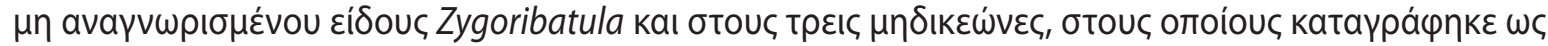

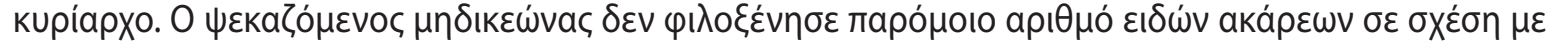

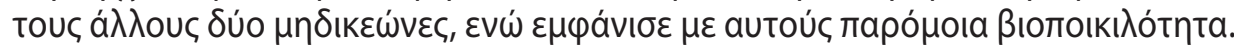

Hellenic Plant Protection Journal 13: 29-41, 2020 